\title{
Evaluation of Antiurolithiatic Potential of Piper cubeba Dried Fruits on Sodium Oxalate Induced Urolithiasis in Rats
}

\author{
Sura Suman ${ }^{1, *}$, Solleti Venkata Suresh Kumar ${ }^{2}$ \\ 'Research Scholar, Department of Pharmacy, JNTUA, Ananthapuramu, Andhra Pradesh, INDIA. \\ 2Department of Pharmacognosy and Phytochemistry, Creative Educational Society's College of Pharmacy, Kurnool, Andhra Pradesh, INDIA.
}

\begin{abstract}
Objectives: The main endeavor of the work is to assess the antiurolithiatic potentials of ethanolic extract of Piper cubeba dried fruits (EEPC). Methods: EEPC was prepared using soxhlation, subjected to phytochemical screening and determined total phenolic and flavonoid content using FolinCiocalteu reagent and aluminium chloride colorimetric assay methods. In vitro antioxidant activity was evaluated using methods like 2,2-diphenyl-1picrylhydrazyl (DPPH) and lipid peroxidation assays using ascorbic acid as standard. Sodium oxalate $(70 \mathrm{mg} / \mathrm{kg}$, i.p) was given to rats for 5 days to promote urolithiasis. Cystone $(750 \mathrm{mg} / \mathrm{kg}, \mathrm{p} .0), \operatorname{EEPC}(100,200$ and 400 $\mathrm{mg} / \mathrm{kg}$, p.o) was administered to the respective group of rats from $6^{\text {th }}$ to $15^{\text {th }}$ day. On the $15^{\text {th }}$ day, serum and urine were collected from individual animals and biochemical parameters like BUN, creatinine and uric acid in serum and sodium, chloride, potassium, calcium, phosphate, oxalate in urine and calcium, phosphate and oxalate in kidney homogenate have been measured. The kidney sections have been prepared and histopathologically tested to check the stones. Results: Preliminary phytochemical analysis discloses the existence of phenolics, tannins, steroids, terpenoids
\end{abstract}

and flavonoids. The EEPC enriched with phenols and flavonoids which correlates with its antioxidant potentials. Following treatment with cystone and EEPC, concentrations of BUN, creatinine, uric acid in serum and sodium, chloride, potassium, calcium, phosphate, oxalate in urine and calcium, phosphate, oxalate in kidney homogenate $(P<0.001$ vs. control) were significantly reduced in urolithiasis caused by sodium oxalate in a dose-dependent way. Conclusion: The promising results suggest that EEPC would act as a potential agent in the management of urolithiasis along with its antioxidant properties.

Key words: Antioxidant, Calcium oxalate, Flavonoid content, Sodium oxalate, Total phenolic content, Urolithiasis.

\section{Correspondence}

Mr. Sura Suman

Research Scholar, JNTUA, Ananthapuramu-515002, Andhra Pradesh, INDIA.

Phone no: +91-9949521100

Email: kalyan.suman1985@gmail.com

DOI: 10.5330/ijpi.2020.3.69

\section{INTRODUCTION}

Urolithiasis implies to the compacted non-metallic aggregates in the urinary tract. Calcium oxalate is the most common of many types of kidney stones. The formation of such calculi involves several physicochemical incidents, starting with the nucleation and aggregation of crystals and ending with urinary tract retention. ${ }^{1}$ Several mechanisms concerned with urolithiasis etiology are among the most significant reasons for the failure to expand antiurolithiatic drugs. Reactive oxygen species (ROS) are recognized to disrupt the oxidant-antioxidant balance in the kidney cells resulting in cellular damage. ${ }^{2}$ Renal epithelial cells induce oxidative stress when exposed to different crystals such as $\mathrm{CaOx}$, calcium phosphate and uric acid. ${ }^{3}$ Hence, the imbalance between lithogenesis promoters and inhibitors contributes to the formation of renal calculi. Therefore, drugs with various targets, such as antioxidant, anti-spasmodic and anti-inflammatory features, are an obvious choice for the development of antiurolithiatic drugs.

Piper cubeba L. or tailed pepper belongs to the family of Piperaceae. This plant is a folk herb and has been used as a spice in many countries, including Indonesia, India, Europe (Middle Ages) and Morocco. As per the classical Unani system of medicine, Piper cubeba (Kabab chini) are reported to be useful in the treatment of a wide range of ailments including a diuretic, lithotriptic, cathartic for kidney and bladder, demulcent, astringent, antiseptic, de-obstructive, hepatotonic, antiinflammatory, mouth Refreshner, stimulant, anti-asthmatic, carminative, sedative, gastrotonic. ${ }^{4-6}$
However, no scientific data are available to develop the antiurolithiatic activity of $P$. cubeba dried fruits ethanolic extract. In the present research, an attempt was made to establish the scientific validity of the antiurolithiatic activity of Piper cubeba dried fruits ethanolic extract against urolithiasis induced by sodium oxalate in rats.

\section{MATERIALS AND METHODS}

\section{Collection of plant material}

The collection of dried fruits of Piper cubeba was done from Sirigiri Venkappa ayurvedic stores, Kurnool, Andhra Pradesh, India in July 2017 for the present study and conformed by Raw material herbarium and museum, NISCAIR, Delhi, India with a reference number (NISCAIR/ RHMD/Consult/2017/3091-40). The dried fruits have been pulverized to get the coarse powder used for extraction.

\section{Preparation of extract}

The coarse powder of Piper cubeba dried fruits crammed in a thimble and was subjected to extraction by using the Soxhlet apparatus, ethanol as a solvent. The extract was filtered and the residue obtained after concentration in the water bath was further evaporated at laboratory temperature and stored in desiccator till use.

\section{Phytochemical screening}

The ethanolic extract of Piper cubeba dried fruits (EEPC) was subjected to preliminary phytochemical screening for alkaloids, glycosides, 
tannins, phenols, steroids, flavonoids and terpenoids following standard procedures. $^{\text {? }}$

\section{Estimation of Phenolic content}

The total phenolic content of the ethanolic extract of Piper cubeba dried fruits $(E E P C)$ was measured by the using Folin ciocalteu process. ${ }^{8} 10 \mathrm{ml}$ stock solution of the extract was prepared in the respective solvent with a concentration of $2 \mathrm{mg} / \mathrm{ml}$. $1 \mathrm{ml}$ of the extract solution was taken into a $25 \mathrm{ml}$ volumetric flask from the stock solution to this $10 \mathrm{ml}$ of water and $1.5 \mathrm{ml}$ Folin ciocalteu reagent added. The mixture was placed aside for $5 \mathrm{~min}$ and then $4 \mathrm{ml}$ of $20 \%$ sodium carbonate solution was added and volume was made up to $25 \mathrm{ml}$ with double distilled water. The mixture was placed aside for $30 \mathrm{~min}$ and the absorbance of blue color formed was quantified at $765 \mathrm{~nm}$. The solutions of standard gallic acid have been prepared in a concentration range of 50 to $250 \mu \mathrm{g} / \mathrm{ml}$ for calibration curve preparation. The standard calibration curve for gallic acid was attained by plotting absorbance on the $y$-axis and their concentration on the $\mathrm{x}$-axis respectively.

\section{Estimation of total flavonoid content}

The total flavonoid content of the ethanolic extract of Piper cubeba dried fruits (EEPC) was estimated by earlier reported methods. ${ }^{9}$

\section{Aluminium chloride method}

The aluminium chloride colorimetric method was carried out using the earlier reported procedure. Quercetin was used to make the calibration curve. From the stock solution of standard, 0.1, 0.2, 0.3, 0.4 and 0.5 $\mathrm{ml}$ were taken which gave $10,20,30,40$ and $50 \mu \mathrm{g}$ concentrations respectively. $0.5 \mathrm{ml}$ of diluted standard solutions were separately mixed with $1.5 \mathrm{ml}$ of $95 \%$ ethanol, $0.1 \mathrm{ml}$ of $10 \%$ aluminium chloride, $0.1 \mathrm{ml}$ of $1 \mathrm{M}$ potassium acetate and $2.8 \mathrm{ml}$ of distilled water. The absorbance of the reaction mixture was measured at $415 \mathrm{~nm}$, after incubation at room temperature for $30 \mathrm{~min}$. the amount of $10 \%$ aluminium chloride was substituted by same amount of distilled water in blank. Similarly, 0.5 $\mathrm{ml}$ of ethanolic extract of Piper cubeba dried fruits (EEPC) was reacted with aluminium chloride for determination of total flavonoid content as described above.

\section{2,4-dinitro phenyl hydrazine method}

The method reported by chang et al. was used for this estimation. Naringenin was used as a reference sample for the preparation of the calibration curve. $20 \mathrm{mg}$ of naringenin was dispersed in methanol and then diluted to provide concentrations of 250, 500, 1000, 1500 and 2000 $\mu \mathrm{g} / \mathrm{ml} .1 \mathrm{ml}$ of each of the diluted standard solutions was independently mixed with $2 \mathrm{ml}$ of 1\% 2,4-dinitro phenyl hydrazine reagent and $2 \mathrm{ml}$ of methanol at $50^{\circ} \mathrm{C}$ for $50 \mathrm{~min}$, after cooling to room temperature the reaction mixture was mixed with $5 \mathrm{ml}$ of $1 \%$ potassium hydroxide in $70 \%$ methanol and incubated at room temperature for $2 \mathrm{~min}$, then $1 \mathrm{ml}$ of the mixture was taken and mixed with $5 \mathrm{ml}$ of methanol and centrifuged at $1000 \mathrm{rpm}$ to remove the precipitate formed. The supernatant was filtered and adjusted to $25 \mathrm{ml}$, the absorbance of the supernatant was measured at $459 \mathrm{~nm}$. Similarly, $5 \mathrm{ml}$ of each concentration of ethanolic extract of Piper cubeba dried fruits (EEPC) were treated with 2,4-dinitro phenyl hydrazine reagent for determination of flavonoid content as described above. For the blank, the amount of 2,4-dinitro phenyl hydrazine reagent was replaced by methanol.

\section{Evaluation of in vitro antioxidant activity of Piper cubeba dried fruits ethanolic extract}

\section{2,2 diphenyl 1 picrylhydrazyl (DPPH) assay}

The Piper cubeba dried fruits ethanolic extract effect on DPPH radical was estimated using the method described by Sharifi-Rad. ${ }^{10}$ A $0.135 \mathrm{mM}$
DPPH methanol solution was formulated as well as its $1.0 \mathrm{ml}$ amount was combined with $1.0 \mathrm{ml}$ amount of Piper cubeba dried fruits ethanolic extract having concentrations $(25-3200 \mu \mathrm{g} / \mathrm{ml})$. The mixture of the reaction was carefully vortexed as well as placed in the shade at $37^{\circ} \mathrm{C}$ room-temperature for $30 \mathrm{~min}$. Spectrophotometrically, at $517 \mathrm{~nm}$ solution's absorbance, is measured. For instance, Ascorbic acid was used. The following equation calculated the scavenge DPPH radical ability "as: $\mathrm{DPPH}$ radical scavenging activity $(\%)=\left[\left(\mathrm{Abs}_{\text {control }}-\mathrm{Abs}_{\text {sample }}\right)\right] /(\mathrm{Abs}$ (trol $) \times 100$

Where Abs ${ }_{\text {control }}$ represents DPPH radical + methanol absorbance; Abs sample represents the DPPH radical + sample extract /standard absorbance.

\section{Lipid peroxidation assay method}

Lipid peroxidation inhibition of EEPC was determined using an earlier reported method. ${ }^{11}$ Further, homogenization of $10 \mathrm{gm}$ of rat liver tissue was done in phosphate buffer solution along with a polytron homogenizer (Remi) having $7.4 \mathrm{pH}$ which produced homogenate of $25 \% \mathrm{w} / \mathrm{v}$. Next, for $10 \mathrm{~min}$ centrifugation of homogenation was done at $4000 \mathrm{rpm}$. Supernatant's $0.1 \mathrm{ml}$ was combined with $0.1 \mathrm{ml}$ of different concentrations of ethanolic extract of Piper cubeba dried fruits (25$3200 \mu \mathrm{g} / \mathrm{ml})$ and $0.1 \mathrm{ml} \mathrm{Kcl}(30 \mathrm{mM}), 0.1 \mathrm{ml}$ "ascorbic acid" $(0.06 \mathrm{mM})$, $0.1 \mathrm{ml}$ "ammonium ferrous sulphate" was added as well as at $37^{\circ} \mathrm{C}$ it was incubated for $1 \mathrm{hr}$. After that, $1.5 \mathrm{ml}$ TBA (0.8\%), $1.5 \mathrm{ml}$ of $20 \%$ glacial acetic acid, as well as sodium dodecyl sulphate $0.2 \mathrm{ml}(8 \%)$ were used to treat the reaction mixture. Distilled water was used so that the total mixture volume is attained was $4 \mathrm{ml}$ and then for $1 \mathrm{hr}$ at $100^{\circ} \mathrm{C}$, it was placed in an oil bath. After the mixture was cooled down, $5 \mathrm{ml} 15: 1 \mathrm{v} / \mathrm{v}$ butanol-pyridine mixture, as well as $1 \mathrm{ml}$ distilled water, is added to it. Furthermore, for $10 \mathrm{~min}$ tubes were centrifuged at $4000 \mathrm{rpm}$ after vigorous shaking. At $532 \mathrm{~nm}$, the organic layer's absorbance is measured that contains TBARS (Thiobarbituric Acid Reactive Substance). Instead of a test compound, $0.1 \mathrm{ml}$ respective vehicle was used for preparing the control sample. It resulted in the $50 \%$ inhibition concentration $\left(\mathrm{IC}_{50}\right)$ and percentage inhibition.

\section{Evaluation of pharmacological studies}

Healthy mice weighing about 20-30 g and rats weighing about 150-180 g are procured from animal house, CES College of pharmacy, Kurnool. They were placed in polypropylene cages and kept under a temperature of $27 \pm 2^{\circ} \mathrm{C}$, relative humidity $65 \pm 10 \%$ and $12 \mathrm{~h}$ light/dark cycles. The animals were given a standard diet manufactured by Nutrivet Life Sciences, Pune, India. The protocol was reviewed and approved by the Committee on Institutional Animal Ethics (Ref. No.: IAEC / CESCOP/2017-10) created following CPCSEA India guidelines.

\section{Acute toxicity studies}

OECD-423 procedures were used to carry out the acute oral toxicity study. ${ }^{12}$ For the effective dosage non-median lethal dose's $\left(\mathrm{LD}_{50}\right) 1 / 10^{\text {th }}$ part is used. ${ }^{13}$

\section{Antiurolithiatic activity}

\section{Sodium oxalate induced urolithiasis in rats}

Antiurolithiatic activity of ethanolic extract of Piper cubeba dried fruits in albino rats was evaluated by using an earlier reported method. ${ }^{14}$ Thirtysix rats have been divided into the following six groups (Normal Control, Disease Control, Standard and 3 Extract Doses) each of which consisted of six rats. $70 \mathrm{mg} / \mathrm{kg}$ of sodium oxalate (in physiologic saline) was given by intraperitoneal injection (i.p) for 5 days to provoke urolithiasis. After induction of urolithiasis, standard drug cystone $(750 \mathrm{mg} / \mathrm{kg}, \mathrm{p.o})$ and three distinct doses of EEPC $(100 \mathrm{mg} / \mathrm{kg}, 200 \mathrm{mg} / \mathrm{kg}$ and $400 \mathrm{mg} / \mathrm{kg}$, p.o) were administered to animals by suspending in $1 \%$ carboxymethyl 
cellulose (CMC) for 10 days. Only a regular diet and potable water were given to normal group rats.On the $15^{\text {th }}$ day, approximately 1.5 to $2 \mathrm{ml}$ of blood was collected through retro-orbital plexus under mild anaesthesia using diethyl ether, ${ }^{15}$ serum was separated by centrifugation at $10,000 \times \mathrm{g}$ for $10 \mathrm{~min}$ and blood urea nitrogen (BUN), creatinine and uric acid were analysed and a 24-hr urine sample had also been collected by putting rats in metabolic cages and drinking water was provided to rats and analysed for sodium, chloride, potassium, calcium, phosphate and oxalate. After blood and urine samples collection, the rats were euthanized using a $\mathrm{CO}_{2}$ chamber and the abdomen was opened to remove both kidneys from each animal. Isolated kidneys have been washed out of extraneous tissue, flushing out of ice-cold physiological saline and the right and left kidneys have been used for homogeneous renal analysis and histopathological analysis, respectively.

\section{Kidney homogenate analysis}

The left kidney was finely chopped and 20\% homogenate has been prepared in Tris-HCl buffer $(0.02 \mathrm{mmol} / \mathrm{l}, \mathrm{pH} 7.4)$. Kidney homogenate was used for assaying tissue calcium, phosphate and oxalate.

\section{Histopathological analysis}

The left kidney was fixed in $10 \%$ neutral formalin buffer, sectioned at $5 \mu \mathrm{m}$ thickness and stained with hematoxylin-eosin dye and mounted with Canada balsam. The histopathological examination of slides was executed under a plain and polarized light microscope (40X) and photographed by an Olympus Digital Camera.

\section{Statistical analysis}

All the values are articulated as mean \pm SEM. The data was statistically analysed by using one-way ANOVA followed Dunnett's $t$-test in GraphPad Prism 5.03 version software.

\section{RESULTS}

\section{Preliminary phytochemical screening of ethanolic extract Piper cubeba dried fruits}

Phytochemical screening discloses the presence of phenolics, tannins, steroids, terpenoids and flavonoids in the ethanolic extract of Piper cubeba dried fruits.

\section{Phenolic content estimation}

Folin ciocalteu process is used for measuring the Piper cubeba dried fruits ethanolic extract's total phenolic content through a standard gallic acid. The phenolic content was attained to be $185.65 \mu \mathrm{g} / \mathrm{ml}$.

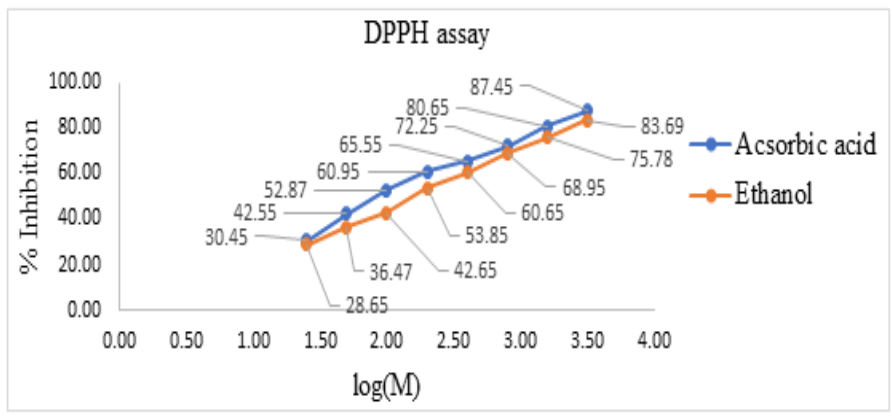

Figure 1: Effect of different concentrations of ascorbic acid and ethanolic extract of Piper cubeba dried fruits on $\mathrm{DPPH}^{*}$ radicals.

\section{Estimation of total flavonoid content}

Piper cubeba dried fruits ethanolic extract's total flavonoid content was determined to be $65.83 \mu \mathrm{g} / \mathrm{ml}$ from the quercetin and naringenin calibration curve.

\section{In vitro antioxidant activity2,2-diphenyl-1-picrylhydrazyl (DPPH) assay}

The effect of ascorbic acid and ethanolic extract of Piper cubeba dried fruits was showed significant DPPH radical scavenging activity. It was thought that the effect of antioxidants on DPPH radical scavenging is due to their capacity to donate hydrogen. The antioxidant activity was obtained to be in a dose-dependent way (Figure 1) and they showed an $\mathrm{IC}_{50}$ value of $185.68 \mu \mathrm{g} / \mathrm{ml}$ and $338.50 \mu \mathrm{g} / \mathrm{ml}$ respectively.

\section{Lipid peroxidation inhibition assay}

The effect of ascorbic acid and ethanolic extract of Piper cubeba dried fruits inhibit the lipid peroxidation induced by $\mathrm{Fe}^{2+}$-ascorbate system in the homogenate of rat liver. Malondialdehyde (MDA) generation and related substances which interact with thiobarbituric acid were identified to be impeded by the ascorbic acid and ethanolic extract of Piper cubeba dried fruit (Figure 2). $\mathrm{IC}_{50}$ value of the ascorbic acid and ethanolic extract of Piper cubeba dried fruits was identified to be $210.45 \mu \mathrm{g} / \mathrm{ml}$ and 495.68 $\mu \mathrm{g} / \mathrm{ml}$ respectively.

\section{Acute toxicity studies}

The limit test was performed with a dose of EEPC (2000 mg/kg, b.w) given by oral route to a group of mice using an oral feed needle (22 gauge). Upon treatment, mice were examined for 14 days and no changes in normal behavior were detected, as a result of which it was concluded that the EEPC was practically non-toxic in normal mice and that the non-medium lethal dose of $1 / 20^{\text {th }}(100 \mathrm{mg} / \mathrm{kg} \mathrm{b.w}), 1 / 10$ th of the dose ( $200 \mathrm{mg} / \mathrm{kg} \mathrm{b.w}), 1 / 5^{\text {th }}$ of the dose $(400 \mathrm{mg} / \mathrm{kg}$ b.w) was considered to be smaller, medium and high doses for further pharmacological studies.

\section{Sodium oxalate induced urolithiasis in rats Serum analysis}

After treatment with sodium oxalate $(70 \mathrm{mg} / \mathrm{kg}$ b.w, i.p) results in a significant increase $\left({ }^{\# \# \#} p<0.001\right)$ in the serum levels of blood urea nitrogen (BUN), creatinine and uric acid when compared to the normal group. These levels were restored significantly $\left({ }^{* * *} p<0.001\right)$ after treatment with standard drug cystone $(750 \mathrm{mg} / \mathrm{kg}$, b.w, p.o). However, treatment with EEPC $(100 \mathrm{mg} / \mathrm{kg}, 200 \mathrm{mg} / \mathrm{kg}, 400 \mathrm{mg} / \mathrm{kg}, \mathrm{p} . \mathrm{o})$ pointedly $\left({ }^{* * *} p<0.001\right)$ restored the elevated levels of blood urea nitrogen, creatinine and uric acid respectively in a dose-dependent manner (Table 1).

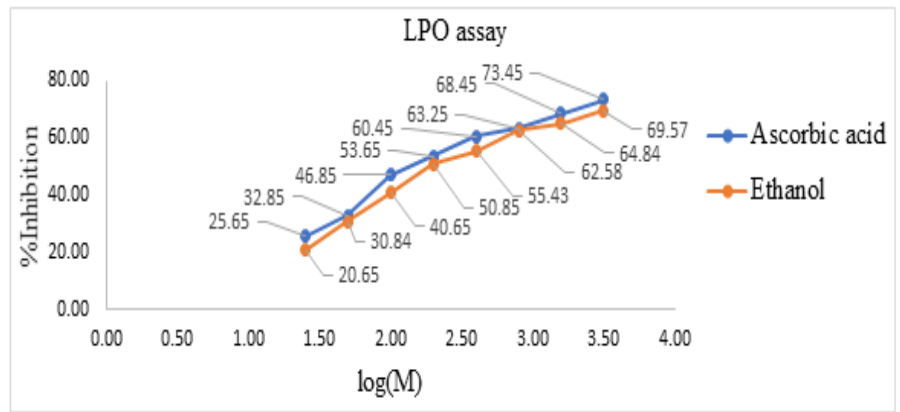

Figure 2: Effect of different concentrations of ascorbic acid and ethanolic extract of Piper cubeba dried fruits on LPO inhibition. 


\section{Urine analysis}

The urinary levels of sodium oxalate $(70 \mathrm{mg} / \mathrm{kg}$ b.w, i.p) administered rats resulted in a significant $(\# \#<0.001)$ increase in excretion of sodium, chloride, potassium, calcium, phosphate and oxalate respectively as compared to normal rats. However, Cystone group rats significantly $\left({ }^{* * *} p<0.001\right)$ and EEPC $(100 \mathrm{mg} / \mathrm{kg}, 200 \mathrm{mg} / \mathrm{kg}, 400 \mathrm{mg} / \mathrm{kg}, \mathrm{p} . \mathrm{o})$ treated rats pointedly reduced the urinary excretion levels of sodium, chloride, potassium, calcium, phosphate and oxalate respectively as compared to disease control of rats (Table 2).

\section{Kidney homogenate analysis}

In the renal tissue, the levels of calcium, phosphate and oxalate were significantly $\left({ }^{\# \# \#} p<0.001\right)$ increased in the sodium oxalate induced rats as compared to normal rats, while in rats treated with cystone $(750 \mathrm{mg} / \mathrm{kg}$, p.o) pointedly reduced the levels of calcium, phosphate and oxalate were significantly $\left({ }^{* * *} p<0.001\right)$ compared to disease control rats. However, rats treated with $E E P C(100 \mathrm{mg} / \mathrm{kg}, 200 \mathrm{mg} / \mathrm{kg}, 400 \mathrm{mg} / \mathrm{kg}$, p.o $)$ significantly $\left({ }^{* * *} p<0.001\right)$ lowered the levels of calcium, phosphate and oxalate respectively than disease control rats (Table 3 ).

\section{Kidney Histopathology}

Histopathological studies of kidney tissue revealed that there were no changes in renal tubules and glomerulus, no deposition of $\mathrm{CaOx}$ in the

\section{Table 1: Effect of EEPC on serum parameters.}

\begin{tabular}{|c|c|c|c|c|}
\hline S.no & Groups & $\begin{array}{c}\text { BUN } \\
(\mathrm{mg} / \mathrm{dl})\end{array}$ & $\begin{array}{l}\text { Creatinine } \\
(\mathrm{mg} / \mathrm{dl})\end{array}$ & $\begin{array}{l}\text { Uric acid } \\
\text { (mg/dl) }\end{array}$ \\
\hline 1 & Normal & $26.29 \pm 1.057$ & $0.50 \pm 0.08$ & $1.16 \pm 0.39$ \\
\hline 2 & Disease Control & $44.51 \pm 1.61^{\# \# \#}$ & $4.46 \pm 0.36^{\# \# \#}$ & $4.60 \pm 0.33^{\# \# \#}$ \\
\hline 3 & $\begin{array}{c}\text { Standard } \\
\text { (Cystone750mg/ } \\
\text { kg, p.o) }\end{array}$ & $29.61 \pm 0.69^{9 * x}$ & $1.74 \pm 0.32^{* * *}$ & $1.98 \pm 0.39^{* * *+}$ \\
\hline 4 & $\begin{array}{c}E E P C(100 \mathrm{mg} / \\
\mathrm{kg}, \text { p.o })\end{array}$ & $35.69 \pm 1.46^{6 * *}$ & $2.26 \pm 0.44^{* * *}$ & $2.33 \pm 0.20^{+* * *}$ \\
\hline 5 & $\begin{array}{l}E E P C(200 \mathrm{mg} / \\
\mathrm{kg}, \mathrm{p} . \mathrm{o})\end{array}$ & $31.18 \pm 1.03^{*+* t}$ & $1.96 \pm 0.30^{* * * *}$ & $2.03 \pm 0.39^{*+* *}$ \\
\hline 6 & $\begin{array}{l}E E P C(400 \mathrm{mg} / \\
\mathrm{kg}, \text { p.o })\end{array}$ & $30.46 \pm 1.28^{*+* x}$ & $1.70 \pm 0.40^{2+* *}$ & $2.01 \pm 0.23^{*+*}$ \\
\hline
\end{tabular}

All values are expressed as mean \pm S.E.M $(n=6)$. Comparisons made between ${ }^{* \# *} p<0.001,{ }^{* \# *} \mathrm{p}<0.01, "{ }^{*} \mathrm{p}<0.05$; Normal Vs Disease control, ${ }^{* * *} p<0.001,{ }^{* * *} p<0.01$, " $p<0.05$; Disease control Vs Treatment: One-way ANOVA followed by Dunnett's $-t$ test. kidney tissues (Figure 3A). The disease group showed marked calcium oxalate crystals deposition, significant tubular dilatation and infiltration (Figure 3B). There was no hemorrhage and no necrosis in the standard drug-treated group (Figure 3C). However, at a dose of EEPC $100 \mathrm{mg}$-the treated group exhibited a reduced amount of calcium oxalate crystal deposition, moderate infiltration but no hemorrhage (Figure 3D), at a dose of $200 \mathrm{mg}$ of EEPC treated group also exhibited mild infiltration but no hemorrhage (Figure E) and EEPC $400 \mathrm{mg}$ treated group exhibited reduced tubular dilation and infiltration (Figure $3 \mathrm{~F}$ ). There was a predominant recovery of $\mathrm{CaOx}$ crystals in renal tissues at all three doses $(100,200$ and $400 \mathrm{mg})$ of EEPC.

\section{DISCUSSION}

A variety of animal models using rats were used to induce calcium oxalate urolithiasis. ${ }^{16}$ Among these methods, the sodium oxalate simulated hyperoxaluria rat model triggers the rapid development of calcium oxalate stones in experimental renal tubules and is therefore commonly used for the rapid screening of antiurolithiatic drugs. ${ }^{17}$

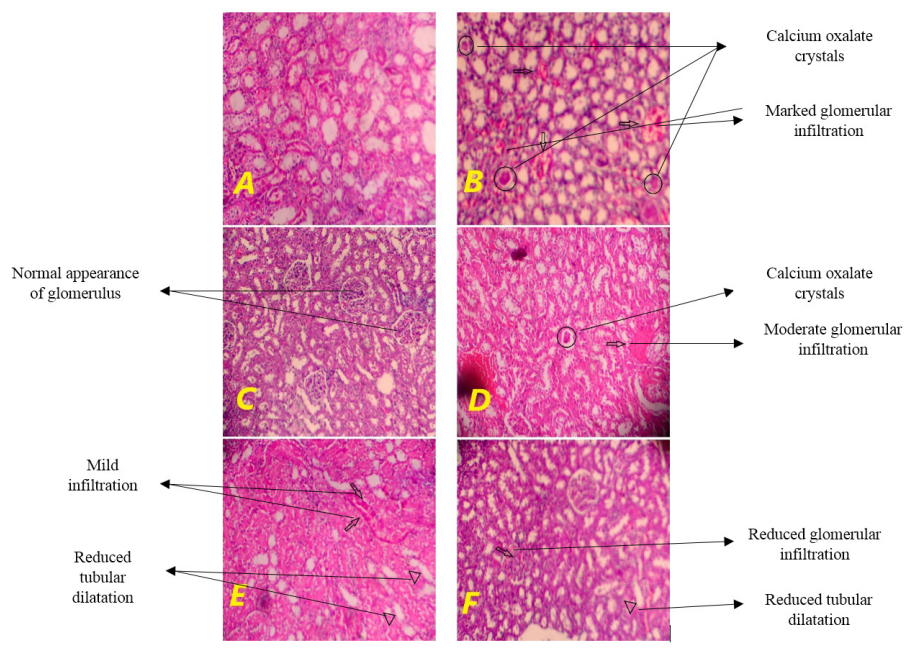

Figure 3: Histopathological appearance of the experimental group rat kidneys stained with hematoxylin and eosin (HE). Sections were viewed using a polarized light microscope (40X) and photographed by an Olympus Digital Camera.

A-Normal group

C- Standard (Cystone $750 \mathrm{mg} / \mathrm{kg}$, p.o)

B-Disease control (sodium oxalate $70 \mathrm{mg} / \mathrm{kg}$ b.w, i.p)

D- EEPC (100 mg/kg, p.o)

EEPC (200 mg/kg, p.o)
F- EEPC (400 mg/kg, p.o)

Table 2: Effect of EEPC on urinary parameters.

\begin{tabular}{|c|c|c|c|c|c|c|c|}
\hline S. No & Groups & $\begin{array}{l}\text { Sodium } \\
(\mathrm{mEq} / \mathrm{L})\end{array}$ & $\begin{array}{l}\text { Chloride } \\
\text { (mEq/L) }\end{array}$ & $\begin{array}{l}\text { Potassium } \\
\text { (mEq/L) }\end{array}$ & $\begin{array}{l}\text { Calcium } \\
\text { (mg/dl) }\end{array}$ & $\begin{array}{l}\text { Phosphate } \\
\text { (mg/dl) }\end{array}$ & $\begin{array}{l}\text { Oxalate } \\
\text { (mg/dl) }\end{array}$ \\
\hline 1 & Normal & $132.6 \pm 2.10$ & $92.28 \pm 1.74$ & $83.12 \pm 2.64$ & $3.06 \pm 0.34$ & $2.66 \pm 0.22$ & $1.84 \pm 0.18$ \\
\hline 3 & $\begin{array}{c}\text { Standard } \\
\text { (Cystone750mg/kg, p.o) }\end{array}$ & $134.6 \pm 2.64^{* * x}$ & $113.2 \pm 2.68^{* * *}$ & $96.61 \pm 3.83^{* * *}$ & $3.88 \pm 0.25^{* * *}$ & $2.47 \pm 0.28^{* * *+}$ & $2.89 \pm 0.32^{* * *+}$ \\
\hline 5 & EEPC (200 mg/kg, p.o) & $141.7 \pm 2.72^{* *+t}$ & $122.9 \pm 3.48^{* * *+}$ & $107.2 \pm 1.45^{*+*}$ & $4.38 \pm 0.23^{* * x+}$ & $2.76 \pm 0.32^{+* *+}$ & $3.23 \pm 0.23^{+x+x}$ \\
\hline 6 & EEPC (400 mg/kg, p.o $)$ & $137.2 \pm 1.91^{* * *}$ & $121.5 \pm 2.43^{*+*}$ & $103.9 \pm 2.33^{* * *+}$ & $4.06 \pm 0.21^{* * *}$ & $2.69 \pm 0.3^{7^{* *} *}$ & $3.06 \pm 0.19^{* * x}$ \\
\hline
\end{tabular}

All values are articulated as mean \pm S.E.M $(n=6)$. Comparisons made between ${ }^{\# * * *} p<0.001,{ }^{* * *} p<0.01,{ }^{*} p<0.05$; Normal Vs Disease control, ${ }^{, * * *} p<0.001,{ }^{* *} p<0.01,{ }^{*} p<0.05$; Disease control Vs Treatment: One-way ANOVA followed by Dunnett's $-t$ test. 
Table 3: Effect of EEPC on renal parameters.

\begin{tabular}{|c|c|c|c|c|}
\hline $\begin{array}{l}\text { S. } \\
\text { No }\end{array}$ & Groups & $\begin{array}{l}\text { Calcium } \\
\text { (mg/dl) }\end{array}$ & $\begin{array}{l}\text { Phosphate } \\
\text { (mg/dl) }\end{array}$ & $\begin{array}{l}\text { Oxalate } \\
\text { (mg/dl) }\end{array}$ \\
\hline 1 & Normal & $0.39 \pm 0.06$ & $1.15 \pm 0.10$ & $2.02 \pm 0.21$ \\
\hline 2 & Disease Control & $1.55 \pm 0.22^{\# \# \#}$ & $3.92 \pm 0.57^{\# \# \#}$ & $4.84 \pm 0.67^{\# \# \#}$ \\
\hline 3 & $\begin{array}{c}\text { Standard } \\
\text { (Cystone } 750 \mathrm{mg} / \mathrm{kg}, \\
\text { p.o })\end{array}$ & $0.55 \pm$ & $1.16 \pm 0.14^{* * *}$ & $2.31 \pm 0.13^{\operatorname{six}}$ \\
\hline 4 & EEPC $(100 \mathrm{mg} / \mathrm{kg}, \mathrm{p} . \mathrm{o})$ & $0.71 \pm 0.22^{* *}$ & $1.95 \pm 0.12^{* *+}$ & $2.76 \pm 0.26^{*+1+}$ \\
\hline 5 & EEPC $(200 \mathrm{mg} / \mathrm{kg}, \mathrm{p} . \mathrm{o})$ & $0.65 \pm 0.13^{* *}$ & $1.87 \pm 0.21^{* * *}$ & $2.64 \pm 0.27^{* * x}$ \\
\hline 6 & EEPC $(400 \mathrm{mg} / \mathrm{kg}, \mathrm{p} . \mathrm{o})$ & $0.58 \pm 0.04^{* * *}$ & $1.68 \pm 0.40^{* * * *}$ & $2.45 \pm 0.24^{n+x *}$ \\
\hline
\end{tabular}

All values are articulated as mean \pm S.E.M $(n=6)$. Comparisons made between ${ }^{* \# *} p<0.001,{ }^{* *} p<0.01,{ }^{*} p<0.05$; Normal Vs Disease control, ${ }^{* * *} p<0.001$, ${ }^{* *} p<0.01,{ }^{*} p<0.05$; Disease control Vs Treatment: One-way ANOVA followed by Dunnett's $-t$ test.

Intraperitoneal administration of sodium oxalate triggers hyperoxaluria in rats. Biochemical pathways for sodium oxalate-induced lithiasis are associated with a rise in the urinary concentration of oxalate. ${ }^{18,19}$ This triggers precipitation of oxalate in the urine as calcium oxalate due to low solubility. High oxalate levels cause several changes in epithelial cells of renal tissue, such as increased production of free radical and decreased antioxidant status, followed by cell damage and cell death. Such changes are important predisposing factors for promoting adherence and retention of crystals. ${ }^{20}$ Oxalate mediated damage and free radical development are attenuated by antioxidants in vivo ${ }^{21}$ and in vitro. ${ }^{22}$ Calculi stimulation with sodium oxalate results in hyperoxaluria. Persistent hyperoxaluria is a more important risk factor for renal stone pathogenesis. ${ }^{23,24}$ Hyperoxaluria can also contribute to the aggregation of calcium oxalate in multiple organs.

In the present study, the administration of EEPC results in a significant decrease in the serum levels of blood urea nitrogen, creatinine and uric acid in a concentration-dependent manner, similar to standard (cystone) drug which was elevated by the renal damage induced by sodium oxalate administration.

In the current research, elevated urinary levels of sodium, potassium, chloride, calcium, oxalate and phosphate were identified in lithiatic rats in line with previously published studies. ${ }^{25}$ However, supplementation with ethanolic extract of $P$. cubeba in different doses leads to a significant decrease in the urinary levels of sodium, potassium, chloride, calcium, oxalate and phosphate respectively as that of standard (cystone) drug compared to lithiatic group.

In line with previous studies, the amount of calcium, oxalate and phosphate in the renal tissue homogenate in the disease control rats was significantly increased compared to normal rats. However, this elevated renal calcium, oxalate and phosphate levels were significantly decreased by treatment with EEPC at dose-dependently as that of standard (cystone) drug compared with the lithiatic group.

Sodium oxalate administration resulted in evident histological changes such as a marked accumulation of calcium oxalate crystals, major tubular dilation, swelling and inflammation of the kidneys, leading to a rise in the index of kidney injury. Treatment with EEPC reversed these histological changes, resulting in a substantial decrease in the damage index. This indicates that the EEPC reduces damage to the renal tubules which might be the partly attributable antioxidant property of the plant. ${ }^{26}$

Overall, this significant recovery in serum parameters, urinary parameters and renal parameters by EEPC in sodium urolithiasis- induced urolithiasis models themselves indicates an extensive range of activity of these extracts covering all phases of pathogenesis. The extent of the action of plant material is primarily determined by the prominent nature of phytochemicals and their contact with each other.

\section{CONCLUSION}

This study demonstrated that the ethanolic extract of Piper cubeba possesses a significant antioxidant and antiurolithiatic activity which might be due to the presence of phytoconstituents like flavonoids, terpenoids and saponins. The different doses of EEPC possess significant activity among in this $400 \mathrm{mg} / \mathrm{kg}$ dose produces potent activity. The mechanism involved in this finding is arbitrated collectively through antioxidant, nephroprotective properties and by reducing the concentration of urinary stone-forming constituents.

\section{ACKNOWLEDGEMENT}

The authors would like to thank the authorities of the Creative Educational Society's College of Pharmacy, Chinnatekur, Kurnool, Andhra Pradesh, India, for providing these facilities.

\section{CONFLICT OF INTEREST}

The authors express that there is no conflict of interest.

\section{ABBREVIATIONS}

CaOx: Calcium oxalate; CMC: Carboxymethyl cellulose; DPPH-2,2: diphenyl-1-picrylhydrazyl; EEPC: Ethanolic extract of Piper cubeba dried fruits.

\section{REFERENCES}

1. Ashok P, Koti BC, Vishwanathswamy $A H$. Antiurolithiatic and antioxidant activity of Mimusopselengi on ethylene glycol-induced urolithiasis in rats. Indian J Pharmacol. 2010;42(6):380.

2. Jyothilakshmi V, Thellamudhu G, Chinta R, Alok K, Anil K, Debadatta N, et al. Beneficial antioxidative effect of the homeopathic preparation of Berberis vulgaris in alleviating oxidative stress in experimental urolithiasis. Complement Med Res. 2014;21(1):7-12.

3. Devkar RA, Chaudhary S, Adepu S, Xavier SK, Chandrashekar KS, Setty MM. Evaluation of antiurolithiatic and antioxidant potential of Lepidagathis prostrata: A Pashanbhed plant. Pharm Biol. 2016;54(7):1237-45.

4. Razi Z, Al-Havi, Al-Kabir. Dairatul Maarif Osmania Hyderabad. 1962;21:391-2.

5. Ibn BZB. Al Jame ul Mufradat al Adviawal Aghziya (Urdu translation). (New Delhi: CCRUM). 2003;4:127-8

6. Zurair AD. Tazkiratuulil Albabwal jameulil Ajab al UjabMatba Al mamaniah Misr. YNM, (I):247-8.

7. Kokate CK, Purohit AP, Gokhale SB. Pharmacognosy, 36 th ed, (Nirali Prakashan, Pune). 2008;593-7.

8. Hmid I, Elothmani D, Hanine H, Oukabli A, Mehinagic E. Comparative study of phenolic compounds and their antioxidant attributes of eighteen pomegranate (Punica granatum L.) cultivars grown in Morocco. Arab J Chem. 2017;10:S267584.

9. Mohy El-Din SM, El-Ahwany AM. Bioactivity and phytochemical constituents of marine red seaweeds (Jania rubens, Corallina mediterranea and Pterocladia capillacea). J Taibah Univ Sci. 2016;10(4):471-84.

10. Sharifi-Rad J, Sharifi-Rad M, Salehi B, Iriti M, Roointan A, Mnayer D, et al. In vitro and in vivo assessment of free radical scavenging and antioxidant activities of Veronica persica Poir. Cell Mol Biol. 2018;64(8):57-64.

11. Ademosun AO, Oboh G, Bello F, Ayeni PO. Antioxidative properties and effect of quercetin and its glycosylated form (Rutin) on acetylcholinesterase and butyryl cholinesterase activities. Evid-Based Compl Alt. 2016;21(4):11-7.

12. Organization for Economic Cooperation and Development. Guidelines for testing of chemicals (OECD-423). 2002.

13. Handa SS, Sharma A. Hepatoprotective activity of andrographolide from Andrographis paniculata against carbontetrachloride. Indian J Med Res. 1990;92:276-83

14. Onaran M, Orhan N, Farahvash A, Ekin HN, Kocabıyık M, Gönül İl, et al. Successful treatment of sodium oxalate induced urolithiasis with Helichrysum flowers. J Ethnopharmacol. 2016;186:322-8.

15. Parasuraman S, Zhen KM, Raveendran R. Retro-orbital sample collection in 
Rats-a video article. PTB Reports. 2015;1(2):37-40.

16. Pawar AT, Vyawahare NS. Protective effect of ethyl acetate fraction of Biophytumsensitivum extract against sodium oxalate-induced urolithiasis in rats. J Tradit Complement Med. 2017;7(4):476-86.

17. Gupta P, Patel N, Bhatt L, Zambare GN, Bodhankar SL, Jain BB, et al. Antiurolithiatic Effect of Petroleum Ether Extract Stem Bark of Crataeva adansonii. in Rats. Pharm Biol. 2006;44(3):160-5.

18. Takawale RV, Mali VR, Kapase CU, Bodhankar SL. Effect of Lagenaria siceraria fruit powder on sodium oxalate induced urolithiasis in Wistar rats. J Ayurveda Integr Med. 2012;3(2):75.

19. Patel N, Badole S, Gupta P, Jain B, Thakurdesai P, Bhardwaj S, et al. Effect of ethanolic extract of leaves of Cocculus hirsutus (L.) diels on experimentally induced urothiliasis in rats. J Nat. 2008;8(1):24-31.

20. Khan SR. Calcium oxalate crystal interaction with renal tubular epithelium, mechanism of crystal adhesion and its impact on stone development. Urol Res. 1995:23(2):71-9.
21. Selvam R. Calcium oxalate stone disease: role of lipid peroxidation and antioxidants. Urol Res. 2002;30(1):35-47.

22. Thamilselvan S, Byer KJ, Hackett RL, Khan SR. Free radical scavengers, catalase and superoxide dismutase provides protection from oxalate-associated injury to LLC-PK1 and MDCK cells. J Urol. 2000;164(1):224-9.

23. Ingale KG, Thakurdesai PA, Vyawahare NS. Effect of Hygrophila spinosa in ethylene glycol induced nephrolithiasis in rats. Indian J Pharmacol. 2012;44(5):639.

24. Divakar K, Pawar AT, Chandrasekhar SB, Dighe SB, Divakar G. Protective effect of the hydro-alcoholic extract of Rubia cordifolia roots against ethylene glycol induced urolithiasis in rats. Food Chem Toxicol. 2010;48(4):1013-8.

25. Bashir S, Gilani AH. Antiurolithiatic effect Bergenia ligulata rhizome: An explanation of the underlying mechanisms. J Ethnopharmacol. 2009;122:106-16.

26. Guruvayoorappan C, Afira AH, Kuttan G. Antioxidant potential of Biophy tum sensitivum extract in vitro and in vivo. J Basic Clin Physiol Pharmacol. 2006:17(4):255-68.

Article History: Submission Date : 14-06-2020; Revised Date : 22-07-2020; Acceptance Date : 06-08-2020.

Cite this article: Suman S, Kumar SVS. Evaluation of Antiurolithiatic Potential of Piper cubeba Dried Fruits on Sodium Oxalate Induced Urolithiasis in Rats. Int. J. Pharm. Investigation, 2020;10(3):390-5 